\title{
STATE OF THE INNOVATIVE SYSTEM OF UKRAINE
}

\section{T. Berezianko}

National University of Food Technologies

\begin{tabular}{l}
\multicolumn{1}{c}{ Key words: } \\
National innovation \\
System \\
Global indexes \\
State policy \\
Public and business \\
interest \\
Innovation structure \\
\hline
\end{tabular}

Article history:

Received 13.07.2018

Received in revised form

30.07.2018

Accepted 13.08.2018

Corresponding author:

T. Berezianko

E-mail:

npnuht@ukr.net

\begin{abstract}
The materials of the research contain the analysis of development state of the Ukrainian innovation system. The concept of alignment, which was replaced by the concept of "designing of profit and profit making nodes", was investigated. This trend was encouraged by the development of globalization processes, in particular competition. The views of domestic scientists on innovation are researched. In one case, innovation is interpreted as the result of the scientific creative process in the form of new technologies, knowledge, methods, etc., and in the other - as a process of introducing new products, principles, elements instead of existing. It has been found that inattention to technical professions is formed in society and transits into family education (parent guidance, negative public experience and media neglect) and schools. We have detected the main problems, restrictive factors, tasks to be solved during the process of stabilization and renewal of national economy. The national innovation system is considered in the context of compliance with the international measurements and the concept of transition to the formation of knowledge society. The aim of this paper is to identify the main disproportions of the development management of the national innovation system. In our study we have used the method of comparison, confrontation, system analysis as well as survey. Research results. It is proved, that the main restrictive factor while forming of comprehensive whole and developing of its breakthroughs is inconsistent, and sometimes destructive management, insufficient activity of public administration and residual financing of needs. For almost 20 years in Ukraine, there were two peaks of innovative financing: both due to external factors. We have identified the differences between the needs of the national innovation system, business expectations and the requirements of international regulators. In general, this can be diagnosed as a consequence of an institutional destructive policy at the state level. Recommendations. Forming of an effective and competitive national innovation system requires the legislative and tool consolidation of innovative development of the country, creation and structuring of the innovation market under national control.
\end{abstract}

DOI: $10.24263 / 2225-2924-2018-24-4-15$ 


\section{СТАН ІННОВАЦІЙНОÏ СИСТЕМИ УКРАÏНИ}

\section{T.В. Березянко}

Національний університет харчових технологій

У матеріалах дослідження проаналізовано стан розвитку інноваційної системи України. Розглянуто концепцію вирівнювання, яка була замінена концепиією проектування вузлів прибутку та отримання прибутку. Ця тенденція зумовлена розвитком прочесів глобалізації, зокрема конкуренції.

Досліджено погляди вітчизняних вчених на інновачії. В одному випадку нововведення інтерпретуються як результат наукового творчого прочесу у вигляді нових технологій, знань, методів тощо, а в іншому - як прочес впровадження нових продуктів, принщипів, елементів замість існуючих. Виявлено, що ігнорування технічних професій сформоване в суспільстві та переходить до сімейної освіти (батьківське керівнищтво, негативний публічний досвід $i$ занедбаність у ЗМІ) та шкіл. Виявлено основні проблеми, обмежувальні чинники, завдання, які потрібно вирішити в процесі стабілізації та відновлення національної економіки. Національна інновачійна система розглядається в контексті дотримання міжнародних вимірювань та концепиії переходу до формування суспільства знань.

Проаналізовано основні диспропориії управління розвитком національної інновачійної системи. Використано метод порівняння, конфронтацію, системний аналіз, а також опитування. Доведено, що основним обмежувальним чинником при формуванні комплексного иілого та розвитку його прориву $\epsilon$ несумісне, а іноді й деструктивне управління, недостатня активність державного управління та залишкове фінансування потреб. Протягом майже 20 років в Украӥні існувало два піки інновачійного фінансування, які були пов'язані із зовнішніми чинниками. Визначено відмінності між потребами національної інноваційної системи, очікуваннями бізнесу та вимогами міжнародних регуляторів. Загалом, ие може бути діагностовано як наслідок інституиійної деструктивної політики на державному рівні. 3 'ясовано, що формування ефективної та конкурентоспроможної національної інновачійної системи вимагає законодавчої та інструментальної консолідаиії інноваційного розвитку країни, створення та структурування інноваційного ринку під національним контролем.

Ключові слова: національна інновачійна система, глобальні індекси, державна політика, інтереси суспільства та бізнесу, інноваційна структура.

Постановка проблеми. Основним засобом отримання конкурентної переваги всі роки становлення національної ринковості залишалось лідирування за витратами, а інструментом його забезпечення стало використання інновацій як джерела вищої продуктивності праці.

3 цією метою було впроваджено концепцію національної інноваційної продуктивності (НІП), за допомогою якої світові рейтингові агенції та економічна спільнота визначали здатність країни (iї політичного та економічного 
управління) розробляти та комерціалізувати потік інноваційних технологій на довгострокових умовах.

Значення інноваційних показників та інноваційної діяльності в нашій країні порівняно з 1990 р. знизилось у 8-15 разів. Аналітики вважають, що це й спонукає ефективні працездатні кадри до активної міграції. Хоча найбільш ефективним інструментом зростання та розвитку визнано продуктивність праці, а найліпшим інструментом іï нарощування $є$ використання інновативних засобів розвитку потенціалу. Рейтингові оцінки України знижуються з року в рік.

Рівень ВВП на душу населення у 2016 р. склав лише 2100 дол. США (найнижчий у Свропі). Якщо порівняти із попередніми значеннями, а саме 3 1990 p. - 1570 дол. США (за даними Світового банку), 1999 р. - 635,9 (40,5\% від рівня 1990 р.), 2004 р. - 1370 дол. США (87,2\% від рівня 1990 р.), 2007 р. — 3069 дол. США (194\%), 2010 р. — 2 545,9 (або 82,9\% від рівня 2007 р.), 2014 р. - 3 014,6 (або на 25\% менше за попередній рік), 2 185,9 (або 54,2\% від рівня 2013 р.), то наявні пікові значення падіння в періоди ліберально-демократичної активізації (2005-2010 pp. та 2013-2016 pp.) [1; 2]. Реальний валовий національний продукт, якщо порівняти 31990 р., становив: у 1999 p. - 43,2\%, у 2004 p. - 61,0\%, у $2010-41,7 \%$, у 2013 p. - 35,4\% [3; 4]. За показником «Ефективність уряду» Україна займає 130 місце із 144 країн.

Лише за рахунок розвитку людського капіталу Україна посідає 31 місце, що відповідає рівню розвинених ринкових країн. 3 огляду на вищевикладене об'єктом дослідження обрано складові національної інноваційної системи.

Аналіз останніх досліджень і публікацій. На сьогодні проблемами розвитку інноваційної діяльності займаються такі науковці: М. Б’юкенен, К. де Брессон, В. Фельдман, Дж. Толенадо, О.І. Амоша, Б.М. Андрушків, 3.С. Варналій, М.В. Геєць, Ж.А. Говоруха, С.Г. Дрига, О.О. Ільченко, В.В. Зянько, І.В. Федулова та інші.

Мета дослідження: визначення проблем створення та реалізації наукових знань, технологій, забезпечення інноваційного процесу та функціонування національної інноваційної системи.

Викладення основних результатів дослідження. Сучасна світова економічна ситуація характеризується певними особливостями, які спонукають до коригування інструментів розвитку економічних агентів. По-перше, раніше успішність економіки та підприємства грунтувалась на контролі над природними ресурсами та капіталом, у теперішній час суспільство існує в умовах «інтелектуальної економіки». По-друге, зростання споживання зумовлене передусім використанням інформаційних продуктів і послуг, а не підвищенням попиту на традиційні масові промислові товари. По-третє, посилюється розрив у суспільному добробуті між країнами, що виробляють інтелектуально-інноваційний продукт, і тими, діяльність яких зосереджена на виробництві промислових товарів. По-четверте, найбільш вагомою компонентою накопичення суспільного багатства стають розвиток індивідуальних здібностей людини, сукупний людський капітал, а найкращими інвестиціями для забезпечення високих ринкових позицій $є$ інвестиції в розвиток людини. 
Наукомісткі технології впливають на стан розвитку суспільства в цілому. Частка технологічних інновацій в обсягу ВВП економічно розвинених країн становить від 70 до 90\% [5]. Західні дослідники оцінюють інноваційну поведінку підприємств як сукупність таких чинників:

1) обсяг змін, які вони викликають в асортименті продукції, процесах виробництва та організації діяльності підприємства;

2) кількість напрямків діяльності підприємства, які вони змінюють;

3) як багато функцій, завдань і методів роботи вони змінюють;

4) наскільки нові вироби та процеси відрізняються від попередніх [6].

Вітчизняні дослідники притримуються двох основних точок зору на інновації. В першому випадку інновація трактується як результат наукового творчого процесу у вигляді нових технологій, знань, методів тощо, а в іншому — як процес впровадження нових виробів, принципів, елементів замість існуючих [7; 8].

У 90-і роки XX ст. США випередили Європу та Японію завдяки концентрації інновацій та стимулювання розвитку галузей промисловості п'ятої хвилі. США отримали скорочення витрат в галузях, що забезпечують інформаційні технології, за рахунок розширення спеціалізації в рамках міжнародного розподілу праці та імміграції, завдяки якій утримувалась низька ставка оплати праці в допоміжних галузях. Крім того, з метою збереження конкурентних переваг було суттєво знижено оплату праці в галузях третьої та четвертої хвилі, що закріпило перевагу за витратами порівняно з Європою.

Інноваційний процес спрямований на створення нових ринків продуктів, технологій та послуг і реалізується в тісній взаємодії з економічним середовищем. Його цілі, темпи та динаміка суттєво залежать від реалій соціальноекономічного середовища, що склалося в виробництві. Базою інноваційного процесу є гармонійне поєднання створення й експлуатації нової техніки $\mathrm{i}$ технологій з інвестиційними механізмами, які забезпечують ії реалізацію. В ринковій економіці галузева та підприємницька наука не зможе займатися цими дослідженнями, звісно, окрім держав-корпорацій. Адже промислові інновації - це результат багаторічних фундаментальних досліджень. Фундаментальна наука в розвитку інноваційних процесів має пріоритетне значення тому, що вона $є$ генератором ідей, відкриває шлях до нових напрямків пошукових досліджень. Так, якщо взяти витрати на фундаментальні дослідження за сто відсотків, то наукові дослідницькі розробки вимагають витрат у квадраті, дослідницько-конструкторські розробки - витрат у четвертому ступені, а впровадження та випуск нового продукту — витрат у восьмому ступені [9].

Забезпеченню реалізації інноваційного шляху розвитку сприяє виважений макроекономічний підхід, коли основою оптимізації стають не тільки інноваційно-інвестиційної політики, але й низка інших напрямків державного регулювання - технологічної, структурної, фіскальної, приватизаційної, соціальної та природоохоронної політики. І головне завдання держави, яка відмовилась від шляху само руйнації, орієнтуватись на мобілізацію внутрішніх ресурсів, відмовитись від зовнішнього керування, яке перетворилось на економічну та інституційну пастку, привести систему управління до національний потреб і зробити ставку на використання людського капіталу. Це і буде найліпшою менеджерською інновацією України. 
У 2017 р. Україна зайняла 50 місце із 127 країн в шкалі Глобального індексу інновацій [10]. Україна займає 101 місце за рівнем показника «Інституції», за рівнем розвитку інфраструктури - 90 місце, показниками ефективності ринків - 43,2, або 81 місце (торгівля і конкуренція - 48, кредити 71, інвестиції - 107), за підпоказником «бізнес-досвід» — 51 місце (за кількістю працівників розумової праці - 41 місце, інноваційними знаннями 72 , сприйняттям знань - 63 місце). При цьому країна демонструє високий рівень результативності наукових досліджень - 32 місце поряд із низьким рівнем впливу їх реалізації - 77. Достатньо високим $\epsilon$ і значення індексу «креативність» - 49 місце, онлайн креативність - 47 місце. В глобальному рейтингу конкурентоспроможності Україна посідає 82 місце між Бразилією та Бутаном.

За критеріями оцінка України складає: частка витрат на науково-дослідницьку діяльність у ВВП - 47; ефективність промисловості - 48; зростання ВВП на душу дорослого населення за три роки - 50; частка місцевих високотехнологічних компаній у бізнесі країни загалом - 32; ефективність вищої освіти - 21; концентрація вчених - 46; патентна активність - 27 .

Довідково: ефективність освіти розраховується як частка дипломованих випускників вищих навчальних закладів до частки випускників з інженернотехнічною освітою. В західних ринкових країнах прийнято університетську освіту відносити до складу академічної та гуманітарної. У свою чергу, конкурентна перевага країни в основному забезпечується за рахунок технікотехнологічної переваги. Тоді стає зрозумілим методичний підхід. В історії ринковості України був період 1990-1995 рр., коли саме ринкові перетворення виштовхнули в сектор непрофільної самозайнятості саме дипломованих спеціалістів інженерного профілю. Неможливість фактичного та достойного працевлаштування за інженерною спеціальність протягом 20 років скоротила до мінімуму бажання отримати технічну освіту в країні (в 2017 р. на факультет механіки в Національному університеті харчових технологій було подано лише три заявки). Ця ситуація стала віддзеркаленням структурних зрушень в економіці та результатом деіндустріалізації країни. Неувага до технічних професій формується в суспільстві і транзитується у сімейне виховання (батьківські настанови, негативний громадський досвід і медійна зневага) та школи (послаблення якості викладання точних наук, особливо в містечках та селищах, відсутність позашкільного заохочення через громадські гуртки технічного розвитку, а також відсутність матеріальної й технічної бази для їх функціонування).

Означений висновок збігається з даними соціологічних досліджень, проведених провідними національними агенціями. Руйнування засобів соціального зростання на базі освіти та спроможності використання навичок у робочій практиці змушує молодь орієнтуватись на суспільства із визначеною та формалізованою програмою набуття високого соціального становища.

У процесі аналізу наведених даних очевидно, що науково та освітньо сформовані орієнтири соціального зростання наявні в європейській системі розвитку особистості та суспільства в цілому. На наш погляд, цей фактор 
значним чином впливає на процес обрання місця та юрисдикції реалізації як молоді, так і професіонально розвинених членів суспільства.

\section{Таблиия 1. Оріснтири соціального зростання, \%}

\begin{tabular}{|c|c|c|c|c|c|c|}
\hline \multirow{2}{*}{ Фактори } & \multicolumn{3}{|c|}{ Україна } & \multicolumn{3}{c|}{ СС } \\
\cline { 2 - 7 } & 2009 & 2012 & 2016 & 2009 & 2012 & 2016 \\
\hline Високий інтелект & 30,3 & 31,8 & 36,6 & 56,1 & 60,8 & 60,1 \\
\hline Вміння обходити закон & 33,1 & 33,1 & 29,2 & 5,3 & 5,5 & 4,7 \\
\hline $\begin{array}{c}\text { Соціальний статус родини } \\
\text { (походження) }\end{array}$ & 37,9 & 38,6 & 33,9 & 24,2 & 22,5 & 14,9 \\
\hline Гарна освіта & 25,8 & 26,4 & 20,7 & 49,0 & 48,4 & 52,2 \\
\hline $\begin{array}{c}\text { Орієнтація на збагачення, } \\
\text { індивідуалізм }\end{array}$ & 46 & 45 & 42 & 47 & 43 & 42 \\
\hline $\begin{array}{c}\text { Можливість самореалізації } \\
\text { у власній країні }\end{array}$ & 66 & 56 & 32 & 83 & 86 & 88 \\
\hline Довіра до системи влади & 23,3 & 28,8 & 10,6 & 63,1 & 67,6 & 55,3 \\
\hline $\begin{array}{c}\text { Важливість ролі науки у } \\
\text { суспільстві }\end{array}$ & 35 & 48 & 34 & 67,3 & 70,2 & 78,3 \\
\hline $\begin{array}{c}\text { Використання владою } \\
\text { рекомендацій національної } \\
\text { науки }\end{array}$ & 33 & 35 & 33 & 58 & 67 & 72 \\
\hline
\end{tabular}

Примітка: укладено за джерелами [11].

Україна має 35 місце в оцінці обов'язкової освіти, 45 - за кількістю дослідників, якістю наукових інститутів - 41, зайнятості - 27, але основною проблемою залишаються нормативні умови ринку праці - 103 місце.

В Україні погіршено рейтингові позиції за всіма складовими індексу «Інновації», крім показника «Наявність учених та інженерів». Найгірший стан у рубриці «Державні закупівлі новітніх технологій і продукції» - 386 позиції на 92, а також у напрямі «Зв'язки університетів 3 промисловістю» - 357 на 73 позицію. І лише на позицією «Доступ до Інтернет на 100 осіб» - наявний позитивний тренд.

Порівняно 3 місцем в інноваційній індексації Європейське інноваційне табло 32010 р. по 2017 р. відбулось погіршення оцінки на 4,2\%. За Глобальним індексом конкурентоспроможності в 2017 р. Україна посіла 69 місце серед 118 країн проти 66 місця в 2016 році. В цілому це можна діагностувати як наслідок інституціональної деструктивної політики на рівні держави.

Однак Україна має виключні позитивні приклади, що реалізовані всупереч ситуації: 7 українців увійшли до переліку 100 найкращих інноваторів Свропи у сферах робототехніки, біосенсорики та комп'ютерної грамоти, виробництва енергоефективних будинків, HR-технологій, медіа та Інтернет засобів [12].

Правова основа ефективної діяльності національної інноваційної системи забезпечується комплексом законів України. У сфері науково-технічної діяльності функціонує понад 25 міжнародних договорів, дія яких створює сприятливі умови для співробітництва та оновлення наукового обладнання. Основними завданнями у сфері співробітництва урядом України визначено заходи (стст.157, 159, 372, 375, 376 Угоди про асоціацію між Україною та Європейським Союзом), втілення яких сприятиме формуванню середовища 3 
передачі технологій і спрощення використання комерційних інноваційних продуктів.

Аналітики відмічають відсутність цілісної системи управління національною інноваційною системою: функції розподілено між Міністерством освіти і науки України та Міністерством економічного розвитку і торгівлі України, що заважає узгодженню між інвестиційною політикою та інноваційними проектами. Крім того, значна кількість обмежувальних заходів Міністерства фінансів України перешкоджає реалізації інновацій і гальмує розвиток науково-технічного потенціалу.

Проте є і позитивні зрушення: в 2016 р. створено окремий Національний комітет з промислового розвитку, в 2017 р. - Національну раду України 3 питань розвитку науки і технологій та Раду з розвитку інновацій. Однак їх діяльність неузгоджена, що не дає змоги забезпечити ефективний вплив на рішення уряду з розвитку інновацій.

Означені проблеми посилюються на рівні регіонів. Зупинено дію багатьох елементів інноваційної інфраструктури, закриті інноваційні парки та інкубатори (2005 p. - законодавче зупинення системи наукових і технологічних преференцій). Роками знаходяться та підправляються на доопрацювання законодавчі пропозиції з покращення й розвитку інноваційної діяльності.

Інноваційна активність підприємств протягом усіх років залишається вкрай низькою. Так, з 2010 р. по 2016 р. обсяг реалізованої інноваційної продукції скоротився на $32 \%$ на внутрішньому ринку і на $21 \%$ - в експорті. Так, в 2016 р. частка високотехнологічної продукції скоротилась на 17\%, а середньотехнологічної - на 43,1\%, якщо порівняти 3 показниками 2002 року. Основним джерелом фінансування залишаються власні кошти підприємств (85\%). Натомість зросла частка низько технологічних галузей до 41,3\%. За даними Державної служби статистики України, у 2016 році лише 18,9\% підприємств впроваджували інновації: лише 723 підприємства впроваджували інновації, 3 яких 400 - застосовували нові технологічні процеси, а 570 реалізували інноваційну продукцію. За даними дослідників, питома вага інноваційної продукції знижувалась у періоди з 2005-2010 рр. та 2013 2017 pp. [13; 14]. Питома вага реалізованої інноваційної продукції неодноразово знижувалась до рівня 3,8\% (2010р.), тоді як у розвинених країнах цей показник стабільно перевищував $20 \%$.

Найбільш активно проводили інновативну діяльність підприємства 3 виробництва харчової продукції, напоїв і тютюнових виробів - 21,6\%.

Аналітики відмічають, що значна частка інновативних заходів припадає на засоби маркетингу та менеджменту, які здебільшого застосовує сектор торгівлі та послуг, а не на техніко-технологічні інновації реального виробництва. Йдеться насамперед про засоби просування продукціï, PR- та HR-діяльність, використання електронної комерції, логістики та мотивації персоналу. На фінансування цього напрямку було витрачено 5,6\% коштів, спрямованих на інновації.

Нами було виконано власне дослідження у період з 2007 р. по 2016 р., хоча й з обмеженим обсягом вибірки. 
Таблиця 2. Основні перешкоди інноваційній активності підприсмств (результати опитування), \%

\begin{tabular}{|c|c|c|c|c|}
\hline \multirow{2}{*}{ Фактори негативного впливу } & \multicolumn{2}{|c|}{ За даними IFC } & \multicolumn{2}{c|}{$\begin{array}{c}\text { Відповіді керівних } \\
\text { працівників підприємств }\end{array}$} \\
\cline { 2 - 5 } & $2000-2004$ & $2007-2016$ & $2000-2004$ & $2007-2016$ \\
\hline Відсутність фінансування & 75 & 23 & 86 & 92 \\
\hline Відсутність коштів у замовників & 50 & 12 & 40 & 50 \\
\hline $\begin{array}{c}\text { Нерозвиненість фінансово-кредитної } \\
\text { системи/високі кредитні ставки }\end{array}$ & 42 & 22 & 39 & 50 \\
\hline Недосконалість законодавства & 25 & 15 & 32 & 38 \\
\hline Нерозвиненість сировинної бази & 15 & 15 & 29 & 29 \\
\hline Високий економічний ризик & 30 & 18 & 24 & 28 \\
\hline Несформований попит & 8 & 10 & 15 & 34 \\
\hline Нерозвиненість міжнародних & 25 & 12 & 11 & 12 \\
\hline $\begin{array}{c}\text { Жв'язків } \\
\text { Жорстке/преференційне державне } \\
\text { регулювання }\end{array}$ & 28 & 10 & 15 & 29 \\
\hline Корупція & 10 & 38 & 12 & 22 \\
\hline Неефективне державне управління & 36 & 22 & 12 & 28 \\
\hline Небажання власника/інвестора & 6 & 6 & 15 & 34 \\
\hline
\end{tabular}

Примітка: укладено за даними статистики та власними опитуваннями.

Україна продовжує втрачати конкурентні позиції на ринках високотехнологічних товарів і послуг. За даними Державної служби статистики України 75\% патентів національних власників втратили чинність через несплату зборів на підтримку дієвості, тільки 7\% патентів використовується в економіці. Причина - відсутність системи стимулів, довготривалий і ресурсовитратний спосіб реєстрації. У свою чергу, це підтримує процес «патентної міграції», який складає щорічно $10-12 \%$.

\section{Висновки}

Систематизація результатів проведеного опитування та дані залучених наукових спостережень і статистики дають змогу зробити такі висновки:

1. За весь період з 2000 р. по 2016 р. не вирішено питання фінансування. Залучення венчурних, позикових та інших ринкових ресурсів мали обмежений та спекулятивний характер і забезпечували лише «зняття вершків». Отримані прибутки виводились за межі країни без залежності від джерела надходження (80\% надходжень поступали з офшорних джерел на короткострокове фінансування розробок).

2. Законодавче регулювання та державне управління мають ситуативний i преференційний характер. Означене питання досліджено в багатьох публікаціях автора.

3. Набули ознак бар'єрів неринкові форми стримування: опортунізм власника, ефект жадібності, ресурсна орієнтація ринків країни.

У результаті проведеного дослідження стану національної інноваційної системи виявлено цілу низку негативних чинників, які стримують ії розвиток. Це насамперед, суперечливі політичні рішення, зниження рівня державної уваги, що вплинуло на характер управлінських рішень, визначення пріори- 
тетів, фінансування, законодавчу підтримку. Особливої уваги вимагає регулювання у сфері інтелектуальної власності.

На наш погляд, потребують подальшого дослідження та порівняння із провідною практикою, насамперед розвинених європейських країн, державне управління інноваційними процесами, належне економічне забезпечення, система прогнозування на дострокову перспективу, цільове забезпечення пріоритетів, а також система освіти, збереження та підтримка національних наукових кадрів.

\section{Лiтература}

1. Свсєєва Г.П., Кривчик Г.Г. Україна vs УРСР: парадигми економічного розвитку [Електронний ресурс] — Режим доступу : http://eadnurt.diit.edu.ua/bitstream/123456789/$3899 / 1 / \% \mathrm{D} 0 \% 94 \% \mathrm{D} 0 \% \mathrm{~B} 2 \% \mathrm{D} 1 \% 96 \% 20 \% \mathrm{D} 0 \% \mathrm{BF} \% \mathrm{D} 0 \% \mathrm{BF} \% \mathrm{D} 0 \% \mathrm{~B} 0 \% \mathrm{D} 1 \% 80 \% \mathrm{D} 0 \% \mathrm{~B} 0 \% \mathrm{D}$ $0 \% \mathrm{~B} 4 \% \mathrm{D} 0 \% \mathrm{~B} 8 \% \mathrm{D} 0 \% \mathrm{~B} 3 \% \mathrm{D} 0 \% \mathrm{BC} \% \mathrm{D} 0 \% \mathrm{~B} 8$.pdf.

2. Валовой внутренний продукт. Минфин - всё о финансах: новости, курсы валют, банки [Електронний pecypc]. - Режим доступу : www.minfin.com.ua/economy/gdp/ Дата публікації: 19.09.2017. — Дата перегляду : 12.12.2017.

3. Висновки щодо виконання Державного бюджету України за 2005 рік - Київ : Рахункова Палата України, 2005. - Випуск 6. - 68 с.

4. Соціально-економічний стан України: наслідки для народу та держави: національна доповідь / за заг.ред. В.М. Гейця [ та ін.]. — Київ : НВЦ НБУВ, 2009. —687 с.

5. Рекомендації парламентських слухань на тему: «національна інноваційна система: стан та законодавче забезпечення розвитку» // Економіст. - 2018. - № 3. - С. 19-25.

6. European Innovation Scoreboard 2016. Belgium : European Commission, 2016. - 96 p. [Електронний ресурс]. — Режим доступу : https://www.google.com.ua.

7. Ілляменко С.М. Управління інноваційним розвитком: монографія / С.М. Ілляшенко, О.А. Біловодська. - Суми : Університетська книга, 2010. - 281 с.

8. Покідіна В. Університети та бізнес: міжнародний досвід співпраці та перспективи для України / Проект «Популярна економіка: ціна держави». - (№ 41) 24 травня 2016 року. - С. 14

9. Kupets $O$. Education in Transition and Job Mismatch: Evidence from the skills survey in non-EU transition economies / Kioto University, Discussion paper. — (№ 915) February 2015 [Електронний ресурс] — Режим доступу : http://repository.kulib.kyotou.ac.jp/dspace/bitstream/2433/195912/1/DP915.pdf.

10. Global Innovation Index [Електронний ресурс] Режим доступу : http:/www.globalinnovatioindex.org/gii-2017-report.

11. Стан сучасного українського суспільства: цивілізаційний вимір / [О.Г. Злобіна, Н.В. Костенко, М.О. Шульга та ін.] за ред.. М.О.Шульги. — Київ, Інститут соціології НАН України, 2017. — 198 с.

12. Сім українців увійшли до New Europe 100 - рейтингу 100 інноваторів Європи [Електронний ресурс] — Режим доступу : https://kfund-media.com/sim-ukrayintsiv-uvijshlydo-new-europe-100-rejtyngu-100-innovatoriv-yevropy/.

13. Дрига С.Г. Інноцид замість інноваційної політики / С.Г. Дрига // Проблеми та перспективи розвитку інноваційної діяльності в Україні: X Міжнародний бізнес-форум (Київ, 21 березня 2017p.) / відп. ред. Мазаракі А.А. — Київ : Київ.нац.торг.-екон.ун-т, 2017. - C. 59-61.

14.Ковальчук С. Сучасний стан інноваційного розвитку промислових підприємств україни / С. Ковальчук // Економіст. — 2012. — № 10. — С. 27-32. 